九州大学学術情報リポジトリ

Kyushu University Institutional Repository

\title{
Crabs from the East China Sea. II : Addition to Brachygnatha Brachyrhyncha
}

Takeda, Masatsune

Zoological Laboratory, Department of Agriculture, Kyushu University

Miyake, Sadayoshi

Zoological Laboratory, Department of Agriculture, Kyushu University

https://doi.org/10.5109/22796

出版情報: 九州大学大学院農学研究院紀要. 15 (4)，pp.449-468，1969-10. Kyushu University バージョン：

権利関係 : 
Journal of the Faculty of Agriculture, Kyushu University, Vol. 15, No. 4

October 30, 1969

Crabs from the East China Sea. II

Addition to Brachygnatha Brachyrhyncha*

Masatsune TAKEDA and Sadayoshi MIYAKE

In the first paper dealt with the crabs from the East China Sea three species of the section Corystoidea and twenty-five species of the superfamily Brachyrhyncha of the section Brachygnatha are enumerated. Of the species referred to the latter section two species of the families Portunidae and Goneplacidae are not named due to the imperfect and young examples. In the present paper ten additional species of the families Portunidae, Xanthidae, Goneplacidae and Palicidae are enumerated from the East China Sea. They are comprised in the recently received collections from the north of Taiwan made by the Taiwan Marine Research Institute, and from off the Danjo Islands. The collection from off Taiwan was at our disposal for study through the courtesy of Mr. II. P. Yu of our laboratory, to whom we express our cordial thanks. The ten additional species are as follows.

\section{Section Brachygnatha}

Superfamily Brachyrhyncha

Family Portunidae

Charybdis cruciata (Herbst, 1794)

Charybdis miles de Haan, 1835

Portunus gracilimanus (Stimpson, 1858)

Portunus hastatoides Fabricius, 1798

Portunus argentatus (A. Milne Edwards, 1861)

Family Xanthidae

Demaniu reynaudii (I-I. Milne Edwards, 1834)

Pilumnus orbitospinis Kathbun, 1911

* Contributions from the Zoological Laboratory, Faculty of Agriculture, Kyushu University, No. 421. 


\title{
Family Goncplacidae \\ Carcinoplax surugensis Rathbun, 1932 \\ Megaesthesius yokoyai Sakai, 1939
}

\author{
Family Palicidae
}

Palicus amadaibai Sakai, 1963

Of the ten species five are referable to the family Portunidae. In the first paper also five species were enumerated and it was accentuated that the collection of portunid crabs is by no means exhaustive. Though altogether ten species are recorded from the Sea to date, it is apparent that more species are found in the further collections. The present five portunid crabs are rather widely distributed in the IndoWest Pacific waters. It is, however, noted that P. gracilimanus is new to the fauna of Japan and its adjacent waters.

One of the two species of the family Goneplacidae, Carcinoplax surugensis, occurs in the Japanese waters from the Sagami Bay southwards to the Tosa Bay. The present specimen was at first identified as C. inaequalis (Yokoya) after comparison with some syntypes of the species. The species is, however, probably synonymous with Rathbun's species, since the ornamentation of the carapace, the armatures of the anterolateral borders of the carapace and the formation of the chelipeds are so similar each other that it is impossible to distinguish the one from the other. It is otherwise noted that Pilumnoplax sp. reported by us in the first paper is referable to Carcinoplax surugensis. An another species of the family, Megaesthesius yokoyai, is very rare and described and figured in detail. It is very characteristic in the formation of the antennules, orbits and eyestalks. It is also noteworthy that several stout hairs along the lower borders of the propodi and dactyli of the ambulatory legs are movable at the bases unlike the usual hairs. Sérène (1964) established a subfamily Chasmocarcininae for the sis genera including the present genus allied to the family Pinnothcridae. According to the paper, the subfamily Chasmocarcininae comprises Chasmocarcinus Rathbun, Chasmocarcinops Alcock, Hephthopel ta Alcock, Camatopsis Alcock, Scalopidia Stimpson and Megaesthesius Rathbun. However, Sérène (1968) included them into the subfamily Typhlocarcinopsinae together with the genera Typhlocarcinops Rathbun, Typhlocarcinodes Alcock and Mertonia Laurie.

As mentioned elsewhere, one of the two species unnamed in the first paper is referable to Carcinoplax surugensis which is dealt with in the oresent paper. Therefore, altogether thirty-seven species of the section Corystoidea and the superfamily Brachyrhyncha of the section Brachygnatha are known to date from the East China Sea. 


\section{Description of species \\ Family Portunidae \\ Genus Charybdis de Haan, 1835}

\section{Charybdis cruciata (Herbst, 1794)}

Charybdis (Goniosoma) crucifera,Alcock, 1899, p. 51 (lit.) - India.

Goniosoma cruciferum, Lanchester, 1901, p. 545 - Trengganu, Malay Penin.

Charybdis crucifera, Stimpson, 1907, p. 80- Hongkong, 10-35 m deep.

Charybdis cruciata, Rathbun, 1910, p. 363 -Gulf of Siam, 30-55 m deep.

Charybdis crucifera, Kemp, 1918, p. 250 - Singora faced to Gulf of Siam.

Charybdis crucifera, Balss, 1922, p. 104 -Taiwan and S. China.

Charybdis (Goniosoma) crucifera, Gordon, 1931, fig. 13, e.

Charybdis (Goniosoma) cruciata, Shen, 1932, p. 38, fig. 6, pl. 8-Hongkong.

Charybdis (Goniosoma) cruciatus, Chopra, 1945, p. 482, fig. 7 - Off River Hooghly, Bay of Bengal.

Charybdis cruciata, Sakai, 1936, p. 124, fig. 58 -Japan.

Charybdis (Charybdis) cruciata, Leene, 1938, p. 24, figs. 1, 2 (lit.) - Java, Bali Sea and Makassnr Str., 20-30 $\mathrm{m}$ deep.

Charybdis cruciata, Sakai, 1939, p. 403, pl. 82, fig. :- Sagami Bay, Kii, Inland Sea and Nagasaki, and Chilung, Taiwan.

Charybdis (Charybdis) cruciata, Stephensen, 1945, p. 114, fig. 24, A -Strait of Hormuz and Gulf of Oman, 12-30 $\mathrm{m}$ deep.

Charybdis cruciata, Barnard, 1950, p. 166, fig. 32, a - Durban, Port Alfred and Delagoa Bay, S. Africa.

Charybdis (Charybdis) cruciata, Stephenson, Hudson and Campbell, 1957, p. 495, figs. 2, E, 3, F, pl. 1, fig. 3, pl. 4, fig. B-Queens., N. S. W., N. Ter. and W. Aust., 10-20 m deep.

Charybdis (Charybdis) cruciata, Miyake, 1961a,p. 18 - Amnkusa Sea.

Charybdis (Charybdis) cruciata, Crosnier, 1962, p. 75, figs. 130-132- Madagascar, 5 $15 \mathrm{~m}$ deep.

Charybdis cruciata, Snkai, 1965, p. 123, pl. 62, pl. 63, fig. 1 - Sagami Bay, 10-20 m deep, Aichi Pref. and Kii.

\section{Material examined.}

Off Chilung, Taiwan ; 1 \& (Length, $31.2 \mathrm{~mm}$; breadth with lateral teeth, $45.2 \mathrm{~mm}$ ), ZLKU No. 13362 ; Nov. 1966 ; Taiwan Mar. Res. Inst. leg.

Distribution. This species bears a wide range in the Indo-West Pacific waters from Japan through the West Pacific to Queensland, Australia and through the coast of India to Madagascar and South Africa. The bathymetric range is from 5 to $55 \mathrm{~m}$, and Crosnier (1962) commented that it is rarely found at the intertidal zone. 


\section{Charybdis miles de Haan, 1835}

Portunus (Charybdis) miles de Haan, 1835, p. 41, pl. 11, fig. 1 -Japan.

Goniosoma miles, A. Milne Edwards, 3861, p. 378 -Japan.

Goniosoma miles, Ortmann, 1893, p. 81 -Tokyo Bay and Kochi.

Charybdis(Goniosoma) miles, Alcock, 1899, p. 62 -Gulf of Martaban, 95 and $120 \mathrm{~m}$ deep.

Charybdis (Gonioneptunus) investigatoris Alcock, 1899, p.70-Off Ganjam coast, Bay of Bengal, $65 \mathrm{~m}$ deep.

Charybdis (Gonioneptunus) investigatoris, Illust. 2001. Invest., 1900, pl. 46, fig. 4.

Goniosoma miles, Whitelegge, 1900,p.157 -Off Newcastle, N.S.W., 40-85 m deep,

Charvbdis miles, Doflein, 1902, p.659- Sagami Bay.

Charybdis miles, Rathbun, 1902, p. 27- Kii.

Charybdis miles, Stimpson, 1907, p. 82 - Hongkong.

Charybdis miles, Parisi, 1916, p. 175 -Tokyo Bay and Sagami Bay.

Charybdis miles, Balss, 1922, p. 104 - Sagami Bay, 50-100 m deep.

Charybdis miles, Yokoya, 1933, p. 175-Kii, Inland Sea, Tosa Bay, Kagoshima Pref. and Koshiki-jima Is., $46-121 \mathrm{~m}$ deep.

Charybdis miles, Sakai, 1934, p. 302 -Nagasaki.

Charybdis (Goniosoma) miles, Chopra, 1935,p. 486, fig. 9 - Off River Hooghly, Bay of Bengal.

Charybdis miles, Sakai, 1936, p. 123, pl.33, fig. 2 -Japan.

Charybdis (Goniosoma) miles, Shen, 1937, p. 123, fig. 13-Off 'I'ioman I., South China Sea.

Charybdis (Charybdis) miles, Leene, 1938, p. 38, figs. 10-13-Borneo Bank, Java Sea and Flores Sea, 59-247 $\mathrm{m}$ deep.

Charybdis miles, Sakai, 1939, p. 405, pl. 46, fig. 2 -Tateyama Bay, Shimoda and Tosa Bay.

Charybdis (Charybdis) miles, Stephenson, Hudson and Campbell, 1957, p.500, fig. 2, H, 3, I, pl.2, fig. 3,pl.4, fig. G -Newcastle and Botany Bay, N. S. W., 40-85 m deep.

Charybdis (Charybdis) miles, Miyake, 1961a,p. 18 - Amakusa Sea.

Charybdis miles, Sakai, 1965, p. 123, pl. 61-Sagami Bay, 15-80 m deep.

\section{M aterial examined.}

Off Chilung, Taiwan ; 1 (Length, $25.7 \mathrm{~mm}$; breadth with lateral teeth, 35 mm), ZLKU No. 13363 ; Nov. 1966 ; Taiwan Mar. Rcs. Inst. leg.

Distribution. This species is widely distributed in the Indo-West Pacific waters from Japan to New South Wales and Western Australia and to the coast of Tndia. The bathymetric range is from 15 to $247 \mathrm{~m}$. 


\section{Genus Portunus Weber, 1795}

\section{Portunus gracilimanus (Stimpson, 1858)}

(Fig. 1)

Amp.itrite gracilimanus, Stimpson, 1907, p. 77, pl. 10, fig. 3 - Hongkong, $30 \mathrm{~m}$ deep. Achelous Whitei A. Milne Edwards, 1861, p. 343, pl. 31, fig. 6 -Borneo.

Neptunus (Achelous) whitei, Miers, 1886, p. 179 -South of New Guinea, $50 \mathrm{~m}$ deep.

Achelous Whitei, Walker, 1887, p. 110 - Singapore.

Achelous Whitei, Henderson, 1893, p. 371 -Gulf of Martaban and Madras.

Neptunus (Lupocycloporus) Whitei, Alcock, 1899, p. 44 - Madras and Andamans.

Achel ous Whitei, Lanchester, 1900, p. 746 -Singapore.

Lupawhitei, Grant and McCulloch, 1906, p. 19 -Port Curtis, Queens.

Neptunus (Lupocycloporus) whitei, Laurie, 1906, p. 416-Gulf of Manaar and off Mutwal I., Ceylon.

Portunus (Lupocycloporus) gracilimanus, Rathbun, 1910, p. 362 - Gulf of Siam, 5-55 m deep.

Neptunus (Lupocycloporus) gracilimanus, Balss, 1922, p.108- Siam.

Neptunus (Lupocycloporus) gracilimanus, Chopra, 1935, p. 481, fig. 6 - Off River Hooghly, Bay of Bengal.

Neptunus (Lupocycloporus) gracilimanus, Shen, 1937, p. 113, figs. 9, 10, c - Singapore

Portunus gracilimanus, Stephenson and Campbell, 1959, p. 115, figs. 2, M, 3, M, pl.

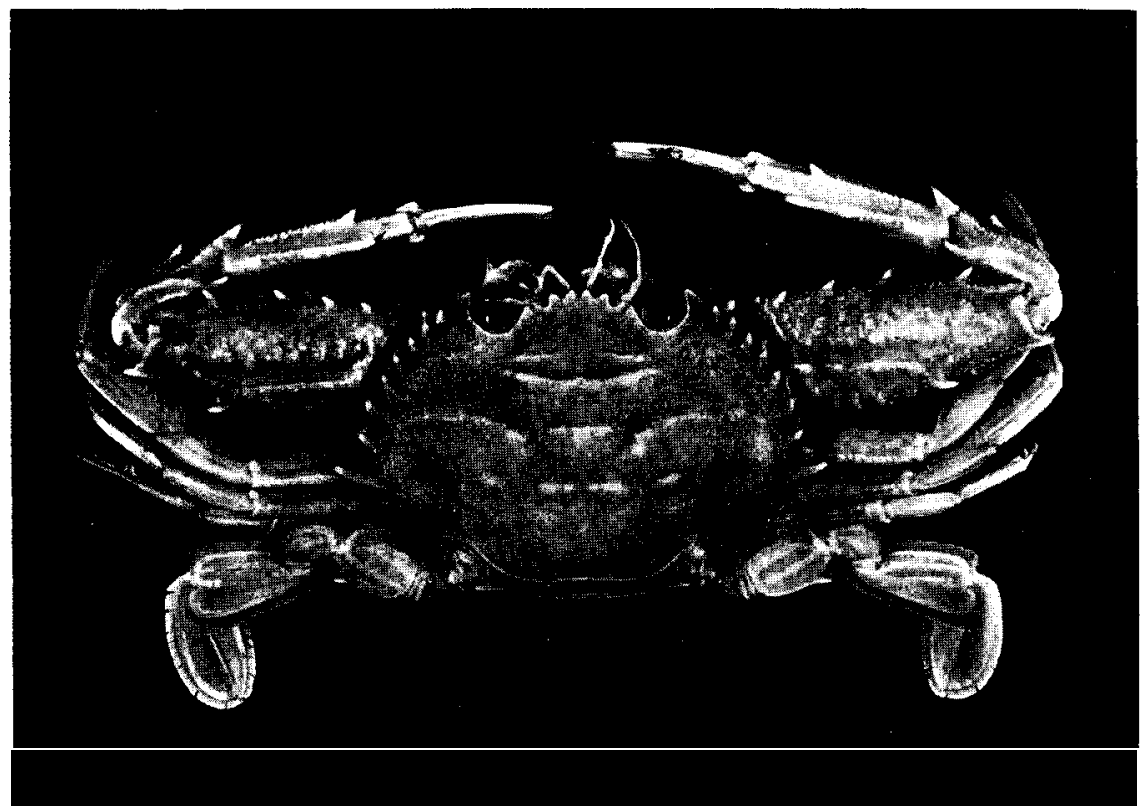

Fig. 1. Portunus gracilimanus (Stimpson), ठ (No. 13366-1). 
4, fig. 1, pl. 4, fig. M, pl. 5, fig. M-Albany Passage, Townsville and Port

Curtis, Queens., $15 \mathrm{~m}$ deep.

\section{Material examined.}

Off Chilung, Taiwan ; $3 \precsim$ (Length, 23.4, 20.8 and $19.6 \mathrm{~mm}$; breadth with lateral teeth, 41.3, 36 and $34.3 \mathrm{~mm}$ ), ZLKU No. 13366; Nov. 1966 ; Taiwan Mar. Res. Inst. leg.

Remarks. It is characteristic that the chelipeds are covered with numerous squamiform granules and a fine pubescence, and that the tips of the fingers are rather prominently curved outwards: In the male abdomen the lateral borders of the ultimate and penultimate segments are not convex or rounded, but almost straight. The first male pleopod is very short and stout, being sharply curved outwards and narrowly tapering at the tip.

As pointed by Stephenson and Campbell (1959), it is less certain whether Portunus innominatus Rathbun substituted for Alcock's Neptunus gracilimanus non Stimpson is distinct from or synonymous with the present species. Judging from the differences enumerated by Alcock (1899) and the statement of Chopra (1935), however, P. innominatus seems to be valid. Though Shen (1937) considers that P. innominatus is a synonym of the present species, here it is therefore excluded from the above synonymy.

Distribution. This species ranges from New Guinea and Hongkong to Queensland, Australia and the Andamans and the east coast of India. It has not been previously recorded from the Japanese waters.

\section{Portunus hastatoides Fabricius, 1798}

Neptunus (Amphitrite) hastatoides, de Haan, 1833, p. 39, pl. 1, fig. 3 -Japan.

Neptunus (Hellenus) hastatoides, Alcock, 1899, p. 38 (lit.)- Persian Gulf, Madras, Andamans, Gulf of Martaban, Penang and Hongkong.

Neptunus (A mphitrite) hastatoides, Lanchester, 1900, p. 745, pl. 45, fig. 7 -Singapore, $10 \mathrm{~m}$ deep.

Neptunus (Hellenus) hastatoides, Borradaile, 1902, p. 208- Maldive Is., $35-55 \mathrm{~m}$ deep.

Portunus hastatoides, Rathbun, 1902, p. 27 - Nagasaki and Kii.

Neptunus (Hellenus) hastatoides, Laurie, 1906, p. 414, fig. 8 - Ceylon, Gulf of Manaar and Palk Bay.

Neptunus (Hellenus) hastatoides var. unidens Laurie, 1906, p. 414 - Gulf of Manaar.

Amphitrite hastatoides, Stimpson, 1907, p. 78 - Hongkong, 10-15 m deep.

Lupa (Hellenus) hastatoides, de Man, 1907, p. 391 - Inland Sea of Japan.

Portunus (Achelous) hastatoides, Rathbun, 1910, p.361-Singapore and Gulf of Siam, 
$5-55 \mathrm{~m}$ deep.

Neptumus (Hellenus) hasratoides, Balss, 192-, p.108-Sagami Bay and Nagasaki, China and Philippines.

Neptunus (Hellenus) hastatoides, Yokoya, 1933, p. 178 - Kii, $46 \mathrm{~m}$ deep.

Neptunus hastatoides, Sakai, 1934, p. 303 - Nagasaki.

Neptunus (Hellenusj hastoides, Chopra, 1935, p. 477, fig.4-Off River Hooghly, Bay of Bengal.

Veptunus (Hellenus) hastatoides, Sakai, 1936, p.130, pl.36, fig. 1 - Japan.

Neptunus (Hellenus) hastatoides, Shen, 1937, p.107, figs. 5, 8, g, l - -Singapore.

Neptunus (Hellenus) hastatoides, Sakai, 1939, pl. 17, fig. 1 -Tateyama Bay, Sagami Bay, Shimoda and Ise Bay.

Neptunus (Hellenus) hastatoides, Stephensen, 19.15, p. 122 -Persian Gulf and Gulf of Oman, 3-70 m deep.

Hellenus hastatoides, Barnard, 1950, p.158, fig. 31, e-g-Zululand.S.Africa, $43 \mathrm{~m}$ deep.

Portunus hastatoides, Stephenson and Campbell, 1959, p.101, figs. 2, I), 3, I), pl. 1, fig. 4, pl. 4, fig. D, pl. 5, fig. D Queens., W. Aust.and N. Ter, 5-15m deep.

Portunus hastatoides, Miyake, 1961a,p.18- Amakusa Sea.

Portunus hastatoides, Miyake, 1961b,p.172-Sea of Ariaké.

Portunus hastatoides, Crosnier, 1962, p. 68, figs. 96, 109, 117, 12:?,12:3 -Madagascar, 7-63 m deep.

Portunus hastatoides, Sakai, 1965, p. 119, pl, 58, fig. 2'-- Sagami Bay, 30-811n deep.

Material examined.

Off Chilung, Taiwan ; 1 (Length, $21 \mathrm{~mm}$; breadth with lateral teeth, $41.4 \mathrm{~mm}$ ), ZLKU No. 13369 ; Nov. 1966 ; 'l'aiwan Mas. Res. Inst. leg.

Distribution. This species is widely distributed in the Indo-West Pacific water-s from Japan to Australia and the east coast of Africa, but it is unrecorded from the Ked Sea. The bathymet ric range is from very shallow water to $80 \mathrm{~m}$.

\section{Portunus argentatus (A. Milne Edwards, 1861)}

Amphitrite argentata White, 1817, p.126(descriptio nulla)-Borneo.

Veptunus argentatus A. Milne Edwards, 1861, p.332,pl.31, fig. 4-Borneo.

Veptunus (Amphitrite) gladiator var. argentatus, Miers, 1886, p. 177 - Celebes Sea, 20-35 m deep.

Veptunus (Amphitrite) gladiator var. argentatus, Ortmann, 1893, p. 7:3-Kagoshima, Japan.

Neptunus argentutus, Henderson, 1893, p.368-Gulf of Martaban.

Veptunus (Amphitrite) argentatus, Alcock, 1899, p.36-Andamans, Mergui, $\Lambda$ rakan

coast, Ganjam coast, Ceylon and Malabar coast, 30-60 m deep.

Neptunus (Amphitrite) argentatus, de Man, 1902, p. 642 -Ternate.

Neptunus (Amphitrite) argentatus, Laurie, 1906, p. 413 -Ceylon and Gulf of Manaar. 
Portunus (Achelous) urgentatus, Rathbun, 1906, p.871-Molokai I., Hawaiian Is.

Neptunus (Amphitrite) argentatus, Sakai, 1939, p. 391, fig. 5, b, pl. 81, fig. 1 -Shimoda, Kii and Tosa Bay.

Monomia argentatus, Barnard, 1950, p. 156, figs. 27, c, 30, a-d -Natal and Delagoa Bay, $50 \mathrm{~m}$ deep.

Portunus (Achelous) argentatus, Edmondson,1954,p. 238, figs.11, 15 - Andamans.

Portunus argentatus, Stephenson, 1961, p.105, figs. 1, F, 3, D, pl. 2, fig. 2, pl.1, fig. D, pl. 5, fig. A -W. Aust., 50-65 m deep.

Portunus argentatus, Crosnier, 1962, p. 50, figs. 71, 75, 77, 80, 81, pl. 3, fig. 1 Madagascar, 10-65 $\mathrm{m}$ deep.

\section{Material examined.}

Off Chilung, Taiwan ; $9 \approx$ (The largest, length, $20.5 \mathrm{~mm}$; breadth with lateral teeth, $39.3 \mathrm{~mm}$ ), 6 ovig. (The largest, length, 20 $\mathrm{mm}$; breadth with lateral teeth, $37.7 \mathrm{~mm}$ : The smallest, length, $14.5 \mathrm{~mm}$; breadth with lateral teeth, $27.9 \mathrm{~mm}$ ), 3 우 (The largest, length, $20.9 \mathrm{~mm}$; breadth with lateral teeth, $38.6 \mathrm{~mm}), 2$ 우우 infested by Sacculina, ZLKU No. 13371 ; Nov. 1966 ; Taiwan Mar. Res. Inst. leg.

Remarks. The first male pleopods arc very well agreeable with the figures given by Stepthnson (1961). It is rather short and strongly curved outwards, being swollen distally.

Distribution. This species is very widely distributed in the whole Indo-West Pacific waters. The records from the Hawaiian waters are, however, somewhat doubtful.

\section{Family Xanthidae \\ Genus Demania Laurie, 1906}

Demania reynaudii (H. Milne Edwards, 1834)

Xantho scaberrimus Walker, 1887, p. 109, pl. 7, figs. 1-4 -Singapore.

Xantho (Lophoxanthus) scaberrimus, Alcock, 1898, p. 316 -Olissa coast, $20 \mathrm{~m}$ deep, and Japan.

Xantho scaberrimus, Rathbun, 1902, p. $2 \overrightarrow{5}-\mathrm{Kii}$, Japan.

Xantho scaberrimus, Rathbun, 1910, p. 350-Gulf of Siam, $55 \mathrm{~m}$ deep.

Xantho scaberrimus, Parisi, 1916, p.180 -Nagasaki.

Lophoxanthus scaberrimus, Balss, 1922, p.126- Hongkong.

Xantho reynaudii, Odhner, 1925, pp. 79, 81 (in discussion).

Lophoxanthus scaberrimus, Yokoya, 1933, p. 189 - Tosa Bay, 97 m deep.

Lophoxanthus scaberrimus, Sakai, 1934, p. 309 - Nagasaki. 
Xantho reynaudii, Sakai, 1936 p.149, fig. 71 -Japan.

Xantho reynaudii, Sakai, 1939, p.461, pl. 40, fig. 1 - Kii.

Lophoxanthus reynaudii, Buitendijk, 1950, p. 77 - Singapore.

\section{Material examined.}

Off Chilung, Taiwan ; 1 ㅇ (Length, $27.8 \mathrm{~mm}$; breadth, $37 \mathrm{~mm}$ ), ZLKU No. 13289 ; Nov. 1966 ; Taiwan Mar. Res. Inst. leg.

Remarks. According to Guinot (1967, pp. 703-704, footnote), the genera Xantho and Lophoxanthus s. str. are at present restricted to the European and American waters, respectively, and thereby the Indo-Pacific species known as belonging to the genera are transferred to the proper genera. As regards the present species Guinot suggested that it is closely allied to the genus Demania Laurie (type-species :D. splendida Laurie). In the first paper of the present study, two specimens are identified as Xantho cultripes Alcock but the generic name should be changed to Demania.

The present species and $D$. cultripes are closely related to D. splendida. Though Balss (1938) was of opinion that D. splendida is synonymous with D. cultripes, as remarked by Buitendijk (1950), D. splendida is distinct from both species on account of bearing the more prominent front, the wider median sinus of the front, and the different formation of the anterolateral border and areolation of the carapace.

Distribution. This species is mainly known from the West Pacific, and otherwise from the coast of India. The localities in the West Pacific are Japan, Hongkong-, the Gulf of Siam and Singapore.

Genus Pilumnus Leach, 1814

\section{Pilumnus orbitospinis Rathbun, 1911}

Pilumnus orbitospinis Rathbun, 1911, p. 229,pl. 16, figs. 1 I, 15- Chagos Arch., 1(X12119 m deep.

Pilumnus orbitospinis, Takeda and Miyake, 1968a, p. 19, fig.4,d-f,pl.3, fig. B (lit,) - Tosa Bay, 150-200 m deep.

\section{Material examined,}

32” 13.6' N, 128” 20.2' E, $167 \mathrm{~m}$ deep ; 1 '(Length, $4.9 \mathrm{~mm}$; breadth without lateral spines, 5.8 mm), ZLKU No. 13404 ; Aug. 6, 1967 ;I. Uchimura leg. 
Remarks. The general appearance of the carapace is somewhat similar to that of P. minutus de Haan, but the anterolateral spines are much slenderer, the inner infraorbital angle is armed with a long spine that is more or less curved dorsally and visible from above, and finally each carpus of the ambulatory legs is unarmed. It is briefly noted here that several specimens reported by Yokoya (1933) as P. hirsutus Stimpson which is synonymous with P. minutus are apparently referable to the present species.

Distribution. This species has hitherto been known from the Chagos Archipelago, the Indian Ocean, and from Japan. In Japan it is known from the Sagami Bay and the Tosa Bay at the depths of 85 to $200 \mathrm{~m}$.

Family Goneplacidae

Genus Carcinoplax H. Milne Edwards, 1852

Carcinoplax surugensis Rathbun, 1932

(Fig. 2)

Carcinoplax surugensis Kathbun, 19:32, p. 34 - Suruga Bay, $265 \mathrm{~m}$ deep.

Pilumnoplax inaequalis Yokoya, 1933, p. 394, fig. 63-South of Inubo-zaki, Suruga Bay, off Shizuoka Pref., Kii, 'Tosa Bay, Bungo Str., off Sata-misaki, Koshikijima Is. and far west of Goto Is., 79-384 $\mathrm{m}$ deep.

Carcinoplax surugensis, Sakai, 1965, p. 167, fig. 21, pl. 8:3, fig. 1 - Sagami Bay, 65$85 \mathrm{~m}$ deep, off Mikawa, 85-120 $\mathrm{m}$ deep and Tosa Bay.

Pilumnoplax sp., Takeda and Miyake, 1968b, p. 565, fig. 6 - East China Sea, $110 \mathrm{~m}$ deep.

Material examined.

32" $14.8^{\prime} \mathrm{N}, 127 ” 59.8^{\prime} \mathrm{E}-32 ” 24.3$ ' N, 128” 7.7’ E, 150-198 m deep ; 1 б (Length, $6.5 \mathrm{~mm}$; breadth without lateral spines, $8 \mathrm{~mm}$; breadth with lateral spines, 9 mm), ZLKU No. 13405 ; Aug. 7, 1967 ; I. Uchimura leg.

Remarks, The present specimen is very well agreeable with the short descriptions of Rathbun (1932) and Yokoya (1933), though those descriptions are too short for the adequate confirmation. Sakai (1965) reported several specimens from the Sagami Bay, off Aichi Prefecture and the Tosa Bay as C. surugensis, and figured the carapace and the tips of the first and second male pleopods. In the present specimen the anterolateral teeth are more distinctly spiniform, tapering regularly. The figure of the pleopods in situ is not available for close comparison 
with the figures represented in the present paper, but they are probably identical.

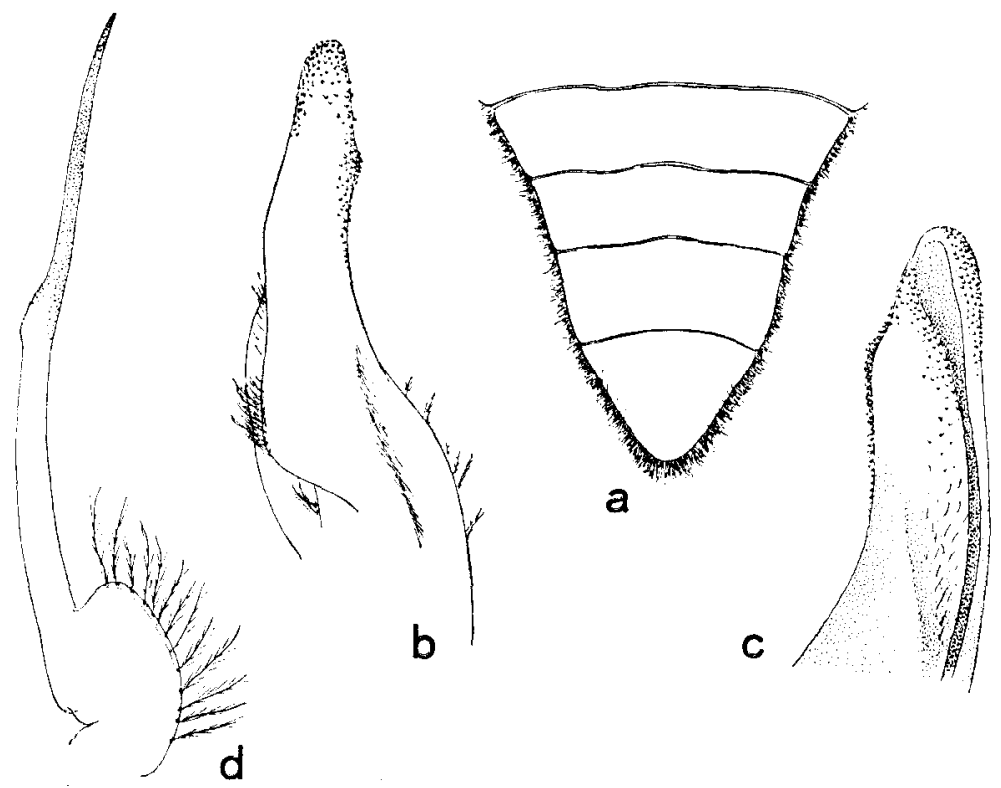

Fig.2. Carcinopfax surugensis Rathbun, $\exists$ (No. 13405).a. Distal four segments of abdomen, $\times 1.3$; b. Left first pleopod in abdominal view, $\times 27$; c. Distal part of the same in sternal view, $\times 41$; d. Left second pleopod in abdominal view, $\times 27$.

At present, in the Zoological Laboratory, Kyushu University are several specimens collected by Soyo-Maru and reported by Yokoya (1933) including some syntypes of Pilumnoplax inaequalis listed below. All the specimens are dry, being in rather good condition.

1) St. 9, south of Inubo-zaki, $238 \mathrm{~m}$ deep. June 22, 1926. 2 if . All the chelipeps and ambulatory legs are missing.

2) St. 194, coast of Maisaka, Shizuoka-ken, $192 \mathrm{~m}$ deep. July 2, 1927. 2 우우.

3) St. 337, north-cast of Ashizuri-zaki, 130 mdeep.July 26, 1928. 1 d. The chelipcds and ambulatory legs arc detached.

In addition to the above specimens, the following specimens mere reported by Yokoya as Pilumnoplax glaberrima Ortmann which is synonymous with Carcinoplax Iongimanus (de Haan). The specimens are dry with an exception of a female from the station 431.

1) St. 179 , near Iro-zaki, $187 \mathrm{~m}$ deep. June $28,1927.1 \delta, 1 \nsucc$. 
2) St. 180, west of Iro-zaki, $276 \mathrm{~m}$ deep. June 28, 1927. 1 ?. All the chelipeds and ambulatory legs are detached.

3) St. 236, north of Suno-saki, $251 \mathrm{~m}$ deep. November 6, 1927. 1 \%

4) St. 304, off southern Miyazaki-ken, $241 \mathrm{~m}$ deep. July 12, 1928. 10, 1 f. The chelipeds and ambulatory legs are detached, and in the female the dorsal surface of the carapace is somewhat damaged.

5) St. 431, south-east of Goto Is., $152 \mathrm{~m}$ deep. July 16, 1929. 1 우․

The following dry male, which is devoid of the chelipeds and ambulatory legs, was listed under the name of Goneplax renoculis Rathbun by Yokoya.

St. 540, near Kyo-gasaki, $123 \mathrm{~m}$ deep. August 25, 1929. $1 \div$.

In all the specimens the dorsal surface of the carapace is somewhat uneven with a transverse depression at the gastro-cardiac separation. The first anterolateral tooth which forms an external orbital angle is always a lobular one with the rounded outer border. The second tooth is as large as the first or only slightly smaller than it, being directed obliquely forwards ; it is very sharp in smaller specimens, but rather obtuse in the larger ones. The third tooth is a slender spine directed obliquely forwards and upwards, and more strongly outwards than in the second. The inner surface of the palm of the cheliped is devoid of a tubercle. It is noted that in the young forms of Carcinoplax longimanus, the first anterolateral tooth is tuberculiform and the inner surface of the palm is armed with a tubercular prominence.

An young specimen reported by us as Pilumnoplax sp. may be referable to this species.

Distribution. This species occurs in the Japanese waters from the south of Inubo-zaki southwards to the south and west of Kyushu along the Pacific coast. Its bathymetric range is from 65 to $384 \mathrm{~m}$.

Genus Megaesthesius Rathbun, 1909

Megaesthesius yokoyai Sakai, 1939

(Figs. 3, 4)

Megaesthesius?sp., Yokoya, 1935, p. 203, fig. 68-Bungo Str., $110 \mathrm{~m}$ deep, and south of Sata-misaki, $249 \mathrm{~m}$ deep.

Megaesthesius yokoyai Sakai, 1939, p. 577 - No new record.

Description. The carapace is subquadrate and strongly arcuated anteroposteriorly, but nearly level from side to side ; the surface is rather ill-defined only with the submedial longitudinal furrows and roughened 
by somewhat scaly minute granules and by rugositics ; near the orbits, front and lateral borbers the scaly granules are rather prominent. The frontal region is well demarcated and strongly convex dorsally, being sulcated in the middle, but in the female the frontal region is not so strongly produced as in the male. The supraorbital border is turned downwards, and its free margin is almost invisible from above ; the dorsal part of the border in dorsal view is almost transverse, slightly retreating backwards near the corner where is obtusely angulated.

The lateral borders of the carapace is parallel to each other ; each of them is provided with three or four notches, of which that in front of the posterior corner is not deep but in reality only a depression. The lobes or teeth thus formed by the notches or depressions are granulated and not strongly protruded from the general contour of the border; of the lobes the last two are armed with spiniform granules, of which one or two of the middle are sometimes much larger than the others. The lateral extremity of the posterior border is prolonged laterally and downwards and armed with several curved spinules; the prolongation is more or less in the appearance of the lobule and visible from above just at the outside of the last two lobes of the lateral border.
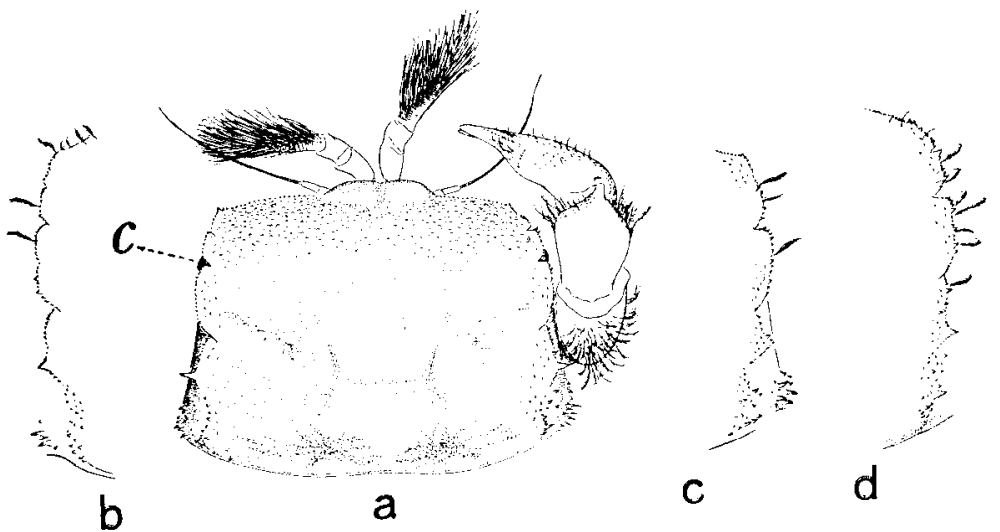

Fig. 3. Megaesthesius yokoyai Sakai. a. Carapacewith right cheliped of (No. 12894-1), $\times$ 7.5; b. Left lateral border of carapace of 3 (No. 19406$), \times 10$; c. Right lateral border of (No.12894-2),, 10 ; d. The same of $\%$ (No. 12893), $\$ 10. Abbreviation. c. Cornea seen in small notch of lateral border of carapace.

The supraorbital and infraorbital borders are granulated and leave a narrow gape near the lateral corner, though they are rather widely separated near the front. The greater part of the long eyestalk is 
tightly embedded in the orbital gape, but the lateral part, about onethird or less the length of the orbit, is folded below the anterolateral border of the carapace ; that exposed part is also immovable in spite of the absence of the fossa; the cornea is well defined and rounded without pigments.

The antennule is enormously stout and fringed with very long silky hairs ; in the male it is especially so and much more stouter than those of the female ; there is no antennular fossa, so that it is wholly visible from above except for the basal segment. The antenna1 basal segment is only slightly shorter but stouter than the second segment; just outside of the basal segment is a subacute small tuberclc of the inner rxtremity of the infraorbital border ; the flagellum is long and slightly excceds the level of the anterolateral border of the carapace, being tipped with two longish silky hairs ; the female flagellum is, however, much shorter and ends far from the level of the anterolateral border, when it is applied to the orbital gape. The pterygostomian region is granulated and swollen, but near the proximal part of the buccal cavity it is rather sunken. The buccal cavity is narrower in front. The third maxillipeds are wide and leave only a very narrow median gape ; the ischium is wide, while the merus is only slighty narrower and somewhat triangular with acute anterior angle; the palp is very short.

Thechelipeds are equal and not much stout in both sexes. The segments are covered with long fine plumose hairs, and unarmed except for minute granules. However, the outer surface of the carpus is almost smooth and devoid of hairs, and the palm is covered with thick granules and sparse hairs. The outer angle of the carpus is articulated with the low tubercle at the proximal middle part of the palm. The inner angle of the carpus is more or less angulated in the male, and armed with a spinule in the female. The chela is compressed, especially the immovable finger is conspicuously so. The lower border of the chcla is prominently crested and almost serrated with a row of spiniform granules. The movable linger is about twice the length of the upper border of the palm and also bears a row of sharp granules along the outer upper border, but not compressed.

The ambulatory legs are long and comparatively slender. The merus is fringed with a distinct row of long, fine plumose hairs, and in addition, bordered with a row of spinules. The carpus bears a fringe of long plumose hairs along the whole length and some spinules near the distal end, The propodus and dactylus are covered with fine hairs of various lengths mixed each with some stout, movable longish setae or hairs that arc mostly implanted along the posterior border.

The male abdomen is composed of five pieces ; the third to fifth segments are fixed and immovable, though the sutures are not entirely 
obliterated ; in reality that between the fourth and fifth segments is possibly observable, and in the inner view those segments are all distinctly traceable.
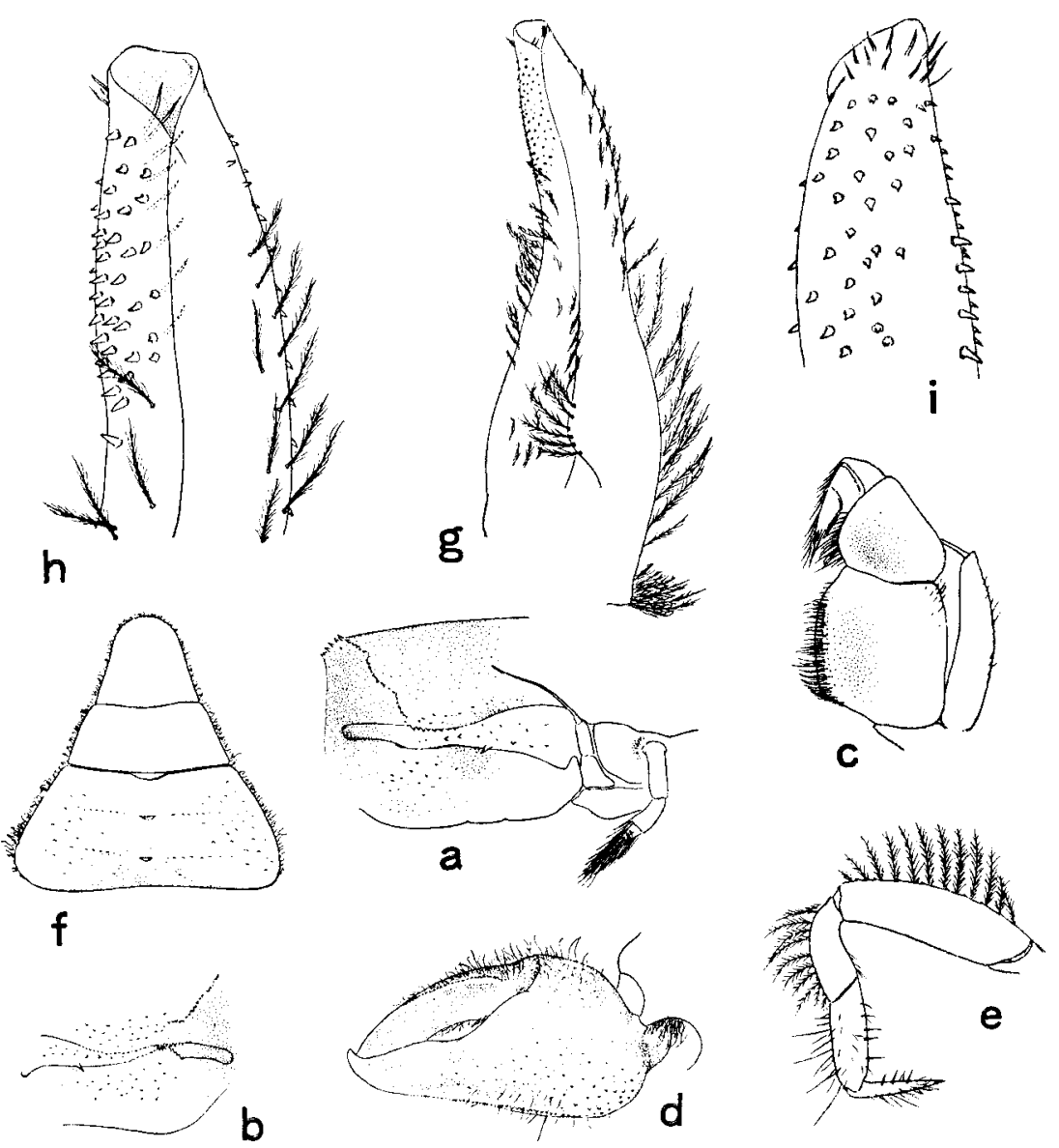

Fig. 4. Megaesthesius yokoyai Sakai. a. Right half of carapace of ? (No. 12893) in frontal view, hairs omitted, $\times 15 ;$ b. Left orbital region of $\cup($ No. 12894-1) in frontal view, $\times 12.5$; c. Left third maxilliped of 0 (No. 12894-1), $\times 17.5$; d. Left chela of 3 (No. 12894-1), $\times 12.5$; e. Left third ambulatory leg of $\delta$ (No. 12894-1), $\times 7.5$; f. Abdomen of (No. 12894-1) without proximal two segments, $\times 12.5$; g. Left first pleopod of $\overrightarrow{0}$ (No. 12894-1) in abdominal view, $\times 40$; h,

i. Distal part of the same in abdominal and sternal view, $\times 100$.

\section{M aterial examined.}

32" 13.5' N, 127" 58.2' E, $147 \mathrm{~m}$ deep ; 1 ठ (Length, $3.8 \mathrm{~mm}$; breadth, $4.9 \mathrm{~mm})$, ZLKU No. 13406 ; Aug. 7, 1967 ; I. Uchimura leg. 
34” 16’ N, 129” 31.5’ E, $105 \mathrm{~m}$ deep ; 1 ð (Length, $3.4 \mathrm{~mm}$; breadth, 4.6 mm), ZLKU No. 12892 ; Aug. 5, 1968 ;'Tsu-shima I. Exp. leg.

34" 17.6 ' N, 129" 48.6' E, $110 \mathrm{~m}$ deep ; 1 우 (Length, $3.7 \mathrm{~mm}$; breadth, 4.8 mm), ZLKU No. 12893 ; Aug. 5, 1968 ;Tsu-shima I. Exp. leg.

34" 25.1' N, 129" 59.3' E, $115 \mathrm{~m}$ deep ; 2 ठ ठ (Length, 3.8 and $3.5 \mathrm{~mm}$; breadth, 5.3 and 4.4 mm), ZLKU No. 12894 ; Aug. 5, 1968 ;'Tsu-shima I. Exp. leg.

Remarks. The original description given by Yokoya (1933) is rather insufficient in some characters. Especially it is noted here that the description about the male abdomen is incorrect and should be revised as being composed of five segments. As regards the other features the present description may supply the short original description.

This distinctive species bearing the peculiar orbit and eycstalk is closely related to the another representative of the genus, $M$. sagedae Rathbun, which was recently well defined by Sérène (1964) who considered the Japanese species is conspecific with it. The present species is, however, distinguished from $\mathbf{M}$. sagedae by some small but distinct features. In the present species the lateral border of the carapace bears some deep indentations, and the chelipeds and ambulatory legs are hairy. In M.sagedae the border is more spiny, and the chelipeds and ambulatory legs are almost naked without long hairs. The third maxilliped of the present species is wider with the more triangular merus and the wider and longer exopod than that of $\mathbf{M}$. sagedae.

At present in the Zoological Laboratory, Kyushu University is one dry male collected by S.S. Soyo-Maru from the station 324, the southern Bungo Strait, $106 \mathrm{~m}$ deep, and reported by Yokoya (1933) as Camatopsis rubida Alcock.

Distribution. This species has hitherto been recorded only from the two localities of the Japanese waters, viz. Bungo Strait and off Satamisaki, Kagoshima Prefecture. The bathymetric range is from 105 recorded at present to $249 \mathrm{~m}$. M. sagedae is known from Singapore and the South China Sea at the depths of 5 and $50 \mathrm{~m}$ respectively.

Family Palicidae

Genus Palicus Philippi, 1838

\section{Palicus amadaibai Sakai, 1963}

Palicus oahuensis, Balss, 1922, p. 120, fig. 6 - Sagami Bay.

Palicus oahuensis, Yokoya, 1933, p.206 - South-east of Inubo-zaki, Suruga Bay and 
south-west of Goto Is., $123-177 \mathrm{~m}$ deep.

Cymopolia oahuensis, Sakai, 1939, p. 609, fig. 90, a - No new record.

Palicus amadaibai Sakai, 1963, p. 227, fig. 7, a- Sagami Bay, 65-85 m deep and Tosa Bay.

Palicus amadaibai, Sakai, 3965, p. 183, pl. 89, fig. 1- Sagami Bay and Aichi Pref., $80-120 \mathrm{~m}$ deep.

\section{Material examined.}

32” 15.1' $N, 127 ” 58.9^{\prime} \mathrm{E}, 149 \mathrm{~m}$ deep ; 1 ð (Length, $10 \mathrm{~mm}$; breadth, 11.8 mm), ZLKU No. 13411 ; Rug. 7, 1967 ; I. Uchimura leg.

Distribution. This species ranges from the south-west of Inubo-zaki southwards to the Tosa Bay, the Pacific coast, and also occurs in the west of Kyushu. The bathymetric range is from 65 to $177 \mathrm{~m}$.

\section{Literature}

Alcock, A., 1898. Materials for a carcinological fauna of India. No. 3. Brachyura Cyclometopa. Part 1. The family Xanthidae. J. Asiat. Soc. Bengal, 67: 67-233.

Alcock, A., 1899. Ditto. No. 4. Brachyura Cyclometopa. Part 2. The families Portunidae, Cancridae and Corystidae. ibid., 68: I-103.

Balss, H., 1922. Ostasiatische Decapoden. IV. Die Brachyrhynchen (Cancridea). Arch. Naturg., ser. A, 88: 95-166, pls. 1, 2.

Balss, H., 1938. Ueber einige Xanthidae (Crustacea Dekapoda) von Singapore und Umgebung. Bull. Raffles Mus., 14: 48-63, pls. 2, 3.

Barnard, K. H., 1950. Descriptive catalogue of South African decapod Crustacea. Ann. S. Afr. Mus., 38: 1-837.

Borradaile, L. A., 1902. Marine crustaceans. I. On varieties. II. Portunidae. In: The fauna and geography of the Maldive and Laccadive Archipelagoes. 1: 191-208.

Buitendijk, A. M., 1950. On a small collection of Decapoda Brachyura, chiefly Dromiidae and Oxyrhyncha, from the neighbourhood of Singapore, Bull. Raffles Mus., 21: 59-82.

Chopra, B., 1935. Further notes on Crustncea Decapoda in the Indian Museum. VIII. On the decapod Crustacea collected by the Bengal Pilot Service off the mouth of the River Iooghly. Brachygnatha (Oxyrhyncha and Brachyrhyncha). Rec. Ind. Mus., 37: 463-514, pl. 9.

Crosnier, A., 1962. Crustacés décapodes, Portunidae. Faune de Madagascar, 16: 1-154, pls. $1-33$.

Doflein, F., 1902. Ostasiatische Decapoden. Aph. K. B. Akad. Wiss., II Cl., 21: 611-670, pls. 1-6.

Edmondson, C., 1954. Hawaiian Portunidae. Occ. Pap. Bernice P. Bishop Mus., 21: 217-274.

Gordon, I., 1931. Brachyura from the coasts of China. J. Linn. Soc. London, Zool., 37: $525-558$. 
Grant, F. E. and A. R. McCulloch, 1906. On a collection of Crustacea from the Port Curtis district, Queensland. Proc. Linn. Soc. N.S.W.. 31: 1-53, pls. 1-4.

Guinot, D., 1967. Recherches préliminaires sur les groupements naturels chezles crustacés décapodes brachyoures. IV. Observations sur quelques generes de Xanthidae. Bull. Mus. Nat. Hist. nat., sér. 2, 39: 695-727.

Haan, W. de, 1833-1850. Crustacea. In: Fauna Japonica sive descriptio animalium, quae in itinere per Japoniam, jussu et auspiciis superiorum, qui summum in India Batava Imperium tenent, suscepto, annis 1823-1830 collegit, notis observationibus et abumbrationibus illustrnvit. i-xvii, i-xxxi, 1-244, pls, 1-55, A-Q , 1, 2.

Henderson, J. R., 1893. A contribution to Indian carcinology. Trans. Iinn. Soc. London, ser. 2, Zool., 5: 325-458, pls. 36-40.

Illustration of the Zoology of the Royal Indian Marine Survey Ship Investigator, under the command of Commander T. H. Heming, R. N. Crustacea, Part VIII, 1900 , pls. $46-48$.

Kemp, S., 1918. Zoological results of a tour in the Far East. Crustacea Decapoda and Stomatopoda. Mem. Asiat. Soc. Bengal, 6: 219-297.

Lanchester, W. F., 1900. On a collection of crustaceans made at Singapore and Malacca. Part 1. Crustacea Brachyura. Proc.zool.Soc. London, 1900: 719-770, pls. 44-47.

Lanchester, W. F., 3901. On the Crustacea collected during the "Skeat" Expedition to the Malay Peninsula, with a note on the genus Actaeopsis. ibid., 3903. :534574, pls. 33, 34 .

Laurie, R. D., 1906. Report on the Brachyura collected by Prof. Herdmann at Ceylon in 1902. Pearl Oysters Fish. Rep., pt. 5, Suppl. Rep., 40: 349-432, pls. $1,2$.

Leene, J. E., 1938. The Decapoda Brachyura of the Siboga-Expedition. VII. Brachygnatha : Portunidae. Siboga-Exped., Monogr. 39c : 1-146.

Man, J. G. de, 1902. Die von Herrn Professor Kiikenthal im Indischen Archipel gesammelten Dekapotlen und Stomatopoden. Abh. Senckenb. nat. Ges., 25: 467929, pls. 19-37.

Man, J. G. de, 1907. On a collection of Crustacea, Decapoda and Stomatopoda chiefly from the Inland Sea of Japan, with descriptions of new species. Trans. linn. Soc. London, ser. 2, Zool., 9: 325-458, pls. 36-40.

Miers, J. E., 1886. Report on the Brachyura collected by H.M.S. Challenger during 187\%1876. Rep. sci. Res. Voy. H. M. S. Challenger, Zool., 17: i-1, 1-362, pls. $1-29$.

Milne Edwards, A., 1861. Etudes zoologiques sur lescrustacés récents de la famille des portuniens. Arch. Mus. Hist.nat., Paris, 10:309-421, pls. 28-38.

Miyake, S., 1961a. Fauna and flora of the sea around the Amakusa Marine Biological Laboratory. Part II. Decapod Crustacea. Amakusa Mar. Biol. Lab., Kyushu Univ., i-iv, 1-30 (in Japanese).

Miyake, S.,1961b. A list of the decapod Crustacea of the Sea of Ariaké,Kyushu. Rec. oceanogr. Wrk. Japan, spec.5: 165-178.

Odhner, T.,1925. Monographierte Gattungen der Krabbenfamilie Xanthidae, I. Göteborgs K. Vet.-och Vit.-Samh. Handl.29: 1-92, pls. 1-5.

Ortmann, A., 1893. Die Decapoden-Krebse des Strassburger Museums, mit beson. derer Berücksichtigung der von Herrn Dr. Döderleinbei Japan und bei den 
Riu-Kiu Inseln gesammelten und zur Zeit im Strassburger Museum anfbewahrten Formen. VII. Brachyura. II. Cyclometopa. Zool. Jahrb., Syst., 7: 411-495, pl. 37. Parisi, B., 1916. I decapodi giapponesi del Museo di Milano. IV. Cyclometopa. Atti Soc. It. Sci. nat., 55:5-42, p1s. 7-11.

Rathbun, M. J., 1902. Japanese stalk-eyed crustaceans. Proc. U. S. Nat. Mus., 26: $28-55$.

Rathbun, M. J., 1906. The Brachyura and Macrura of the Hawaiian Islands. U. S. Fish Comm. Bull. for 1903, 23: 827-930, pls. 1-9.

Rathbun, M. J., 1909. New crabs from the Gulf of Siam. P'roc.biol.Soc. Wash., $22: 107-114$.

Rathbun, M. J., 1910. The Danish Expedition to Siam 1899-1900. V. Brachyura. D. Kgl. Danske Vidensk. Selsk. Skrifter, 7: 303-367, pls. 1, 2.

Rathbun, M. J., 1911. The Percy Sladen Trust Expedition to the Indian Ocean in 1905. 3 (11). Marine Brachyura. Trans. Linn. Soc. London, ser. 2, Zool, 14 : 191-261, pls.15-20.

Rathbun, M. J., 1932. Preliminary descriptions of new species of Japanese crabs. Proc. biol.Soc. Wash., 45: 29-38.

Sakai, T., 1934. Brachyura from the coast of Kyushu, Japan. Sci. Rep. Tokyo Bunrika Daigaku, sec. B, 1: 281-330.

Sakai, T., 1936. Crabs of Japan. 66 plates in life coloures with description. Tokyo, $1-239,1-12$, pls, 1-66, frontispiece (in Japanese).

Sakai, T., 1939. Studies on the crabs of Japan. IV. Brachygnatha, Brachyrhyncha. Tokyo, 365-741, pls. 42-111.

Sakai, T., 1963. Description of two new genera and fourteen new species of Japanese crabs from the collection of His Majesty the Emperor of Japan. Crustaceana, $5: 213-233$.

Sakai, T., 1965. The crabs of Sagami Bay. Tokyo, i-xvi, 1-206, 1-92, 1-32, pls. $1-100$.

Sérène, K., 1964. Redescription du genre Megaesthesius Rathbun et définition des Chasmocarcininae, nouvelle sous-famille des Goneplacidae (Decapoda Brachyura). Crustaceana, $7: 375-187$.

Sérène, R., 1968. The Brachyura of the Indo-West Pacific region. Singapore, 33-112.

Shen, C. J., 1932. The crabs of Hong Kong. Part 3. Hong Kong Nat., 3: 32-45, pls. 6-9.

Shen, C. J., 1937. Notes on a collection of swimming crabs (Portunidae) from Singapore. Bull. Reffles Mus., 13: 96-139.

Stephensen, K., 1945. The Brachyura of the Iranian Gulf. Danish sci. Invest. Iran, 4: $57-237$.

Stephenson, W., 1961. The Australian portunids (Crustacea:Portunidae). V. Recent collections. Aust. J. mar. freshw. Res, 12:92-128, pls. 1-5.

Stephenson, W. and B. Campbell, 1959. Ditto. III. The genus Portunus. ibid., IO: 84-124, pls. $1-5$.

Stephenson, W., Hudson, J. and B. Campbell, 1957. Ditto. I. The genus Charybdis. ibid., 8: 491-507, pls. 1-5.

Stimpson, W., 1907. Report on the Crustacea(Brachyura and Anomura) collected by the North Pacific Exploring Expedition 1853-1856. Smiths. misc. Coll., 19: 1-240, pls. 1-26.

Takeda, M. and S. Miyake, 1968a. Pilumnid crabs of the family Xanthidae from 
the West Pacific. I. Twenty-three species of the genus Pilumnus, with description of four new species. OHMU, Occ. Pap. Zool. Lab. Fac. Agr. Kyushu Univ., 1: 1-60, pls. 1-4.

Takeda, M. and S. Miyake, 1968b. Crabs from the East China Sea, I. Corystoidea and Brachygnatha Brachrhyncha. J. Fac. Agr., Kyushu Univ., 14 :541-582, pl. 6.

Walker, A. O., 1887. Notes on a collection of Crustacea from Singapore. J. Linn. Soc. London, Zool., 20: 107-117, pls. 6-9.

White, A., 1847. List of the specimens of Crustacea in the collection of the British Museum. London, i-viii, 1-143.

Whitelegge, T., 1900. Scientific results of the Trawling Expedition of H. M. C. S. "Thetis," off the coast of New South Wales, in February and March, 1898. Part 2. Crustacea. Part I. Mem. Aust. Mus., 4: 135-199, pls. 32-35,

Yokoya, Y., 1933. On the distribution of decapod crustaceans inhabiting the continental shelf around Japan, chiefly based upon the materials collected by S. S. Soyo-Maru, during the year 1923-1930. J. Coll. Agr. Tokyo Imp. Univ., 12 : $1-226$. 